\title{
OCENA MOŻLIWOŚCI ROZWOJU TURYSTYKI W GMINIE ŁUKÓW
}

\section{ASSESSMENT OF TOURISM POTENTIAL IN ŁUKÓW DISTRICT}

\author{
Agnieszka Kozak ${ }^{1(\mathrm{~A}, \mathrm{~B}, \mathrm{C}, \mathrm{D}, \mathrm{E}, \mathrm{F}, \mathrm{G})}$, Dorota Mączka ${ }^{1(\mathrm{~A}, \mathrm{~B}, \mathrm{C}, \mathrm{D}, \mathrm{E}, \mathrm{F}, \mathrm{G})}$
}

${ }^{1}$ Państwowa Szkoła Wyższa im. Papieża Jan Pawła II w Białej Podlaskiej

Kozak A., Mączka D. (2017), Ocena możliwości rozwoju turystyki w gminie Łuków. Rozprawy Społeczne, 11 (2), s. $45-49$.

Wkład autorów:

A. Zaplanowanie badań

B. Zebranie danych

C. Dane - analiza i statystyki

D. Interpretacja danych

E. Przygotowanie artykułu

F. Wyszukiwanie i analiza

literatury

G. Zebranie funduszy

Tabele: 0

Ryciny: 0

Literatura: 5

Otrzymano: 14.01.2016

Zaakceptowano: 09.02.2016

\begin{abstract}
Streszczenie
Celem opracowania jest przedstawienie możliwości rozwoju turystyki w gminie Łuków oraz odpowiedź na pytanie, czy można uznać, że na tym obszarze istnieje szansa na rozwój turystyki? Celem pracy jest również ocena potencjału turystycznego gminy Łuków i okolic na podstawie opinii mieszkańców, osób odwiedzających omawiany teren a także na podstawie analizy SWOT. W celu oceny potencjału turystycznego gminy Łuków posłużono się metodą sondażu diagnostycznego wspartą kwestionariuszem ankiety. Badania przeprowadzono w 2014 roku na terenie Gminy Łuków. Badaniem objęto 50 osób. Respondentami byli mieszkańcy oraz osoby przyjezdne. W badaniach wykorzystana została również analiza SWOT. Z uzyskanych danych wynika, że gmina Łuków posiada znaczny potencjał turystyczny, przejawiający się przede wszystkim w bogactwie walorów przyrodniczych, historycznych oraz kulturowych. Ponadto gmina posiada dobre położenie komunikacyjne oraz dysponuje dobrze rozwiniętą bazą gastronomiczną i noclegową. Odczuwalny jest jednak brak promocji, inicjatyw władz wspierających rozwój turystyki oraz brak wizerunku turystycznego obszaru.
\end{abstract}

Słowa kluczowe: turystyka, potencjał turystyczny, środowisko przyrodnicze

\section{Summary}

The main goal of the article is to present the possibilities of tourism development in Łuków district and the nearby areas so as to answer the question whether the area is an attractive one for its development. The other aim is to evaluate tourism potential of Łuków and its vicinity basing on opinions of the residents, the people visiting that place and SWOT analysis.

In order to analyze the potential of Łuków district, a questionnaire was used, which was further supported by SWOT analysis. The study was conducted in 2014 in Łuków district and involved 50 persons, mainly the residents and tourists. The obtained results indicated that, despite some shortcomings connected mainly with lack of promotion or initiatives on the part of local authorities supporting tourism development, the district possesses considerable natural, historical and cultural values. Further, it has a favourable geographical location and well-developed catering and accommodation sphere.

Keywords: tourism, tourism potential, natural environment

\section{Wstęp}

Stan środowiska przyrodniczego w połączeniu z ciekawym krajobrazem kulturowym postrzegany jest obecnie jako jeden z najważniejszych czynników kształtujących wielkość i strukturę ruchu turystycznego. Turystyka jest obecnie istotnym czynnikiem rozwoju wielu polskich gmin. Rozwój turystyki na obszarach wiejskich stanowi nowy kierunek w przemianach społeczno - gospodarczych obszarów nieznanych turystycznie. Pozwala także na wykorzystanie zasobów lokalnych, uzyskanie dodatkowych dochodów, rozwój przedsiębiorczości i ekonomicznego ożywienia tych terenów. Duże znaczenie mają obecnie działania marketingowe, zwłaszcza w zakresie promocji. Władze lokalne przy współpracy z różnymi instytucjami powinny podjąć działania na rzecz kształ- towania świadomości turystycznej mieszkańców i ich przedsiębiorczości. Ważne jest również odpowiednie kształtowanie świadomości społeczności lokalnej, popularyzowanie idei rozwoju turystyki, jak i pobudzanie do wykorzystania własnego potencjału intelektualnego i rzeczowego. Takie podejście może sprawić, że ludność lokalna zacznie dostrzegać nowe możliwości, które mogłyby w przyszłości wywrzeć ogromny wpływ na popyt turystyczny w ich gminach, a także w konsekwencji na poziom jakości ich życia.

Celem opracowania jest przedstawienie możliwości rozwoju turystyki w gminie Łuków oraz odpowiedź na pytanie, czy można uznać, że na tym obszarze istnieje szansa na rozwój turystyki? Celem pracy jest również ocena potencjału turystycznego gminy Łuków i okolic na podstawie opinii mieszkańców, osób odwiedzających omawiany teren a także na podstawie analizy SWOT.

\footnotetext{
Adres korespondencyjny: Agnieszka Kozak, Państwowa Szkoła Wyższa im. Papieża Jana Pawła II w Białej Podlaskiej, ul. Sidorska 105, 21-500 Biała Podlaska, e-mail: agatau@tlen.pl, tel.: 833449902

Copyright by: Państwowa Szkoła Wyższa im. Papieża Jana Pawła II w Białej Podlaskiej, Agnieszka Kozak, Dorota Mączka

Czasopismo Open Access, wszystkie artykuły udostępniane są na mocy licencji Creative Commons Uznanie autorstwa-użycie niekomercyjne-na tych samych warunkach 4.0 Międzynarodowe (CC BY-NC-SA 4.0, http://creativecommons.org/licenses/by-nc-sa/4.0/).
} 


\section{Materiał i metody badań}

W celu oceny potencjału turystycznego gminy Łuków posłużono się metodą sondażu diagnostycznego wspartą kwestionariuszem ankiety. Badania przeprowadzono w 2014 roku na terenie Gminy Łuków. Badaniem objęto 50 osób. Respondentami byli mieszkańcy oraz osoby przyjezdne. W badaniach wykorzystana została również analiza SWOT.

Z uzyskanych danych wynika, że gmina Łuków posiada znaczny potencjał turystyczny, przejawiający się przede wszystkim w bogactwie walorów przyrodniczych, historycznych oraz kulturowych. Ponadto gmina posiada dobre położenie komunikacyjne oraz dysponuje dobrze rozwiniętą bazą gastronomiczną i noclegową. Odczuwalny jest jednak brak promocji, inicjatyw władz wspierających rozwój turystyki oraz brak wizerunku turystycznego obszaru.

\section{Charakterystyka gminy Łuków}

Tereny, na których położona jest gmina Łuków, pierwotnie należały do Małopolski. Gminę w obecnych granicach utworzono w 1973 roku. W jej skład, obok gminy Łuków weszły także gminy Gręzówka i Aleksandrów oraz w części gminy Nurzyna i Ulan. W 1975 r. Gmina Łuków znalazła się w granicach nowo utworzonego województwa siedleckiego, jako autonomiczna jednostka administracyjna. Pod względem administracyjnym, od 1 stycznia 1999 roku gmina Łuków należy do województwa lubelskiego i wchodzi w skład powiatu łukowskiego. Gmina Łuków usytuowana jest w północno-zachodniej części województwa lubelskiego, przy granicy z województwem mazowieckim. Cechuje ją stosunkowo dobra dostępność komunikacyjna. Położona jest wokół miasta Łuków, które stanowi ponadregionalny węzeł komunikacyjny, w którym zbiegają się drogi i linie kolejowe o znaczeniu krajowym i ponadregionalnym. Sprawia to, że gmina ma bardzo dobre powiązania komunikacyjne, zarówno z krajem, jak i regionem.

Pod względem fizyczno-geograficznym gmina Łuków położona jest w obrębie Niżu Środkowopolskiego (mezoregion Równina Łukowska). Rzeźba terenu gminy Łuków jest słabo zróżnicowana. Teren jest lekko pofalowany o łagodnych spadkach 2 - $5 \%$. Wysokości bezwzględne wahają się w granicach 154 - 183 m. Największe wzniesienia występują w północnozachodniej i północnej części gminy, na terenie kompleksu leśnego i w okolicach wsi Biardy. Występują tu pagórki żwirowo piaszczyste i wydmy, będące pozostałością moren ze zlodowacenia środkowopolskiego. Wyraźniejsze obniżenie terenu występuje w dolinie Krzny Północnej i Krzny Południowej, biorących swój początek w bagnach rezerwatu przyrody Jata (Program Ochrony Środowiska dla Gminy Łuków...). Gmina Łuków jest gminą rolniczą. Głównymi elementami środowiska przyrodniczego, które decyduja o możliwościach rozwoju rolnictwa gminy są: gleby, klimat, warunki wodne i rzeźba terenu. W gminie
Łuków sektor rolny i działalność gospodarcza około rolnicza ma bardzo duże znaczenie społeczno-gospodarcze. Rolnictwo jest główną gałęzią gospodarki, która ma znaczący wpływ na poziom rozwoju gminy i standard życia mieszkańców. Większość gospodarstw rolnych na terenie gminy Łuków to gospodarstwa indywidualne (rodzinne) o dość słabej kondycji ekonomicznej. Przyczyną jest duże rozdrobnienie i niska towarowość produkcji rolniczej, a także systematycznie rosnące koszty produkcji.

Walory przyrodnicze gminy Łuków oraz liczne pamiątki historyczne są atutem sprzyjającym rozwojowi czynnego wypoczynku w formie wędrówek pieszych i rowerowych. W związku z rozwojem turystyki wyznaczono ok. $70 \mathrm{~km}$ oznakowanych turystycznych szlaków rowerowych. W celu ułatwienia rekreacyjnego korzystania z lasu Nadleśnictwo Łuków urządziło 12 parkingów leśnych, 4 miejsca postoju pojazdów oraz 2 miejsca biwakowe. Miejsca te zostały wyposażone w zadaszenia, ławy, stoły i kosze. Z myślą o młodzieży oraz osobach zainteresowanych przyrodą utworzono ścieżkę ekologiczno-edukacyjną w rezerwacie „Jata”. Ma ona $6 \mathrm{~km}$ długości i pozwala zapoznać się tajemnicami lasu oraz pracami w nim wykonywanymi. W głębi lasów znajdują się również pomniki upamiętniające czyny zbrojne powstania styczniowego oraz II wojny światowej.

Poza walorami przyrodniczymi na terenie gminy znajduje się wiele cennych obiektów dziedzictwa kulturowego: zespoły dworsko-pałacowe, cmentarze, miejsca pamięci narodowej, kapliczki, figury i krzyże przydrożne, oraz inne zabytki architektury i budownictwa. Najcenniejszymi spośród nich, będącymi zarazem atrakcjami turystycznymi są:

- zespół dworsko-parkowy w Ryżkach,

- pomnik ku czci księdza Stanisława Brzózki w pobliżu Dąbrówki, położony w Lasach „Jata”,

- pomnik ku czci partyzantów AK w pobliżu Gręzówki, położony w lasach „Jata”,

- pomnik partyzantów polskich i radzieckich w pobliżu miejscowości Żdżary, położony w lasach „Jata”,

- zespół dworski w Kownatkach,

- kapliczka drewniana w Gręzówce,

- zespół folwarczny i zespół leśniczówki w Kryńszczaku.

Atrakcyjne tereny gminy stanowią doskonałe miejsce weekendowego wypoczynku dla mieszkańców Łukowa i pobliskich miast. Odczuwa się jednak brak sieci obiektów o charakterze rekreacyjno-rozrywkowym. Podstawę bazy turystycznej gminy Łuków stanowi położony w Gręzówce ośrodek szkoleniowo-wypoczynkowy „Jagódka” dysponujący 20 miejscami noclegowymi w pokojach 1-4 osobowych. Ponadto na terenie gminy zarejestrowanych jest siedem gospodarstw agroturystycznych, a ich liczba systematycznie się zwiększa.

Gmina Łuków jest gminą o cennych walorach przyrodniczo-krajobrazowych. $\mathrm{Na}$ terenie Gminy znajduje się14 406 ha obszarów prawnie chronionych. Obszary chronione, coraz bardziej doceniane 
przez turystów, stanowią w tej gminie , aż 46,7\% jej powierzchni, podczas gdy średnio w województwie odsetek obszarów prawnie chronionych kształtuje się na poziomie $23 \%$, zaś w kraju - 33\%. Na terenie gminy Łuków występują 4 ciekawe rezerwaty przyrody, w tym: 3 rezerwaty florystyczne: „Jata”, „Topór” i „Las Wagramski” oraz rezerwat geologiczny pod nazwą „Kra Jurajska”.

Rezerwat „Jata” jest najstarszym i największym z czterech powołanych na obszarze gminy rezerwatów. Rezerwat położony jest w leśnictwach Dąbrówka i Jata. Powstał w 1933 r., jego całkowita powierzchnia wynosi 1 116,9 ha, z czego 337,4 ha podlega ścisłej ochronie. Według głównego przedmiotu ochrony jest to rezerwat florystyczny. Przez rezerwat płyną rzeki: Krzna Południowa i Krzna Północna, których doliny porośnięte są przez bory jodłowe z udziałem świerku i sosny. Osobliwością rezerwatu jest jodła objęta całkowitą ochroną. Poza jodłą występują tu 100-160-letnie starodrzewy dębów, świerków, sosen, grabów, lip, klonów, wiązów, olch i jesionów. Innymi gatunkami roślin chronionych występującymi na terenie rezerwatu są: widłaki, wawrzynek wilcze łyko, kruszczyk szerokolistny, storczyki i paprocie.

"Jata" odznacza się również bogactwem fauny. Występuje tu wiele gatunków ptaków zagrożonych wyginięciem np.: cietrzew, żuraw, bocian czarny, orlik krzykliwy, brodziec samotny, słonka, trzmielojad, kilka gatunków dzięciołów; ssaki np.: sarny, dziki, jelenie, łosie, wilki, lisy, borsuki; gady np.: zaskrońce, żmije zygzakowate padalce. Rezerwat „Topór”, w przeciwieństwie do rezerwatu Jata, zajmuje dość niewielki obszar - 58,2 ha. Znajduje się w północno - zachodniej części kompleksu Kryńszczak. Według głównego podmiotu ochrony jest to rezerwat florystyczny, którego celem ochrony jest stanowisko jodły, natomiast według głównego typu środowiska jest to rezerwat lasów i borów. Obok jodły rosną tu dęby, sosny, świerki, brzozy, osiki, graby, lipy, jawory. Z mniejszych zaś gatunków: widłaki, paprocie, wawrzynek wilczełyko, jeżyna gruczołowata. Jest najdalej na północny - zachód Europy wysuniętym stanowiskiem jodły. Las Wagramski jest rezerwatem florystycznym, utworzonym w 1980 r. w celu ochrony wawrzynka główkowego, wysuniętego tu najdalej na północ Europy. Położony jest w południowo - wschodniej części gminy na terenach Nadleśnictwa Radzyńskiego, zajmuje powierzchnię5,37 ha. Inne rośliny chronione rezerwatu to np.: podkolan biały, lilia złotogłów, orlik pospolity, janowiec ciernisty, wężymord niski. Rezerwat „Kra Jurajska” jest rezerwatem geologicznym, położonym na terenach wsi Gołaszyn, zajmuje powierzchnię 8 ha. Pokłady czarnego iłu jurajskiego występujące $\mathrm{w}$ rezerwacie zawierają skamieniałe muszle głowonogów, w tym amonitów i belemnitów, małży, ślimaków, otwornic, wężowideł, ramienionogów, mszywiołów i liliowców. Z tej różnorodności fauny kry jurajskiej niewątpliwie najbardziej opisane i najbardziej znane w świecie sa amonity kry jurajskiej. Celem rezerwatu jest ochrona i zachowanie złoża amonitów, występujących w krze jurajskiej już na głębokości $2 \mathrm{~m}$. Rezerwat jest atrakcją przyrodniczą o randze międzynarodowej. Zachowane skamieniałe muszle amonitów powstały ponad 100 milionów lat temu i są ewenementem w skali światowej (Program Ochrony Środowiska dla Gminy Łuków...).

Łuków jest także miejscowością o bardzo bogatej przeszłości historycznej. Nazwa Łuków jest najprawdopodobniej związana $\mathrm{z}$ topografią terenu i bierze początek Od prasłowiańskiego rdzenia „łęg”, „łuk” lub „ług”, co oznacza nizinę, obszar bagnisty wzdłuż rzeki. Najstarsze dzieje miasta nie są wyjaśnione z uwagi na niewielką ilość przekazów źródłowych. Sytuacja taka nie pozwala na dokładne ustalenie daty powstania miasta. Należy jednak przypuszczać, że miasto zostało założone w celach militarnych w II połowie XII lub na początku XIII w. przez któregoś z książąt piastowskich. Z kronik wiadomo, że w 1233 roku Łuków był siedzibą kasztelanii. Położony wśród puszcz i bagien był ważnym punktem strategicznym (Szczęśniak 1984).

Współczesny Łuków to miasto w którym władze kładą nacisk na rozwój. Na przestrzeni ostatnich lat powstało wiele ośrodków m.in. Ośrodek Sportu i Rekreacji, Łukowski Klub Sportowy „ORLĘTA ŁUKÓW”, Państwowa Szkoła Muzyczna, Kino „OAZA”, Szpital, Pogotowie Ratunkowe przychodnie i gabinety. Na terenie gminy działają lokalne gazety takie jak: Gazeta Łukowska, Wspólnota Łukowska, Dziennik Wschodni oraz telewizja MASTER TV. Znacząco rozwinęła się baza noclegowa: Hotel „MIŚ, Hotel „GROCHOWSKI” ,Hotel „KORONA”, Zajazd „ZIMNA WODA”.

\section{Atrakcyjność turystyczna Łukowa i okolic w opinii mieszkańców}

W ankiecie przygotowanej dla mieszkańców i turystów, obok pytań dotyczących atrakcyjności walorów turystycznych zawarto pytania odnośnie wybranych aspektów atrakcyjności turystycznej badanego obszaru. Respondenci, do elementów, które mogą decydować o atrakcyjności obszaru zaliczyli: możliwość dojazdu do badanego obszaru (dostępność turystyczną), stan środowiska, obecność zabytków, obecność ciekawych obszarów chronionych w postaci rezerwatów przyrody (potencjalna turystyka dla hobbystów, ornitologów, edukacyjna), podejście mieszkańców do turystów oraz zadowalający stan zagospodarowania turystycznego. W opinii władz lokalnych i mieszkańców najważniejszym walorem badanego terenu jest stan środowiska przyrodniczego, oddalenie od wielkomiejskich aglomeracji a w dalszej kolejności wykreowanie ciekawych, konkurencyjnych produktów turystycznych. Społeczność lokalna podkreślała rolę historii i tradycji ludowych. Jednak z wyników analizy, są one najprawdopodobniej zbyt mało znane odwiedzającym lub po prostu nieciekawe. Do najmniej istotnych walorów zaliczono zabytkowe cmentarze, kapliczki i krzyże przydrożne oraz obszary prawnie chronione. Może to wynikać z faktu, że są to walory wciąż mało spopularyzowane. Brak wiedzy o nich powoduje, że są jedynie walorem po- 
tencjalnym, nieistniejącym w świadomości turystów i lokalnej społeczności.

Z przedstawionej analizy wynika, że turystyka w gminie Łuków bazuje przede wszystkim na walorach przyrodniczych. Zostały one ocenione przez respondentów jako najbardziej atrakcyjne. Z drugiej strony, obszar ten charakteryzuje się również ciekawym dziedzictwem historycznym.

Należałoby zdecydowanie podjąć liczne inicjatywy w celu popularyzacji zasobów niematerialnych regionu, ponieważ są one zbyt mało znane nie tylko turystom, ale i samym mieszkańcom, ponadto nie są wystarczająco wykorzystane jako atut turystyczny obszaru.

\section{Analiza SWOT gminy tuków}

Zestawienie szans i zagrożeń z mocnymi i słabymi stronami danego obszaru pozwala na określenie pozycji strategicznej, a także może być źródłem ciekawych pomysłów. Podkreślić należy, iż analiza SWOT ma zawsze subiektywny charakter, tak w zakresie czynników wewnętrznych, jak i czynników otoczenia. To, co dla jednej organizacji (przedsiębiorstwa, instytucji, regionu) może być szansą, okazją do wykorzystania, dla innej może stanowić zagrożenie przeszkodę lub nawet barierę rozwoju (Romanowska, Gierszewska 2003).

Analiza SWOT dla gminy Łuków i jego okolic została opracowana na podstawie własnych obserwacji Autorek artykułu jak również opinii osób biorących udział w przeprowadzonej ankiecie. Jest ona również wynikiem spostrzeżeń mieszkańców oraz osób przebywających na terenie gminy. Analiza potencjału turystycznego gminy Łuków oraz jej okolic dokonana za pomocą metody SWOT, jednoznacznie wskazuje jej atuty i słabości oraz szanse (okazje) i zagrożenia kreowane przez jego otoczenie, ich ocena natomiast powinna pozwolić na sformułowanie strategii rozwoju funkcji turystycznej odnośnie tego obszaru.

\section{MOCNE STRONY}

- atrakcyjne położenie geograficzne blisko dużych miast tj. Warszawa, Siedlce, Lublin, Biała Podlaska,

- dobre położenie komunikacyjne przy głównym szlaku kolejowym,

- dużo terenów zielonych, lasów, rezerwatów przyrody, parków,

- czyste powietrze,

- mało zdegradowane środowisko przyrodnicze,

- sztuczny zbiornik wodny „ Zimna Woda”

- dobrze prosperująca branża obuwnicza i mięsna (zrównoważony rozwój turystyki)

- bogate dziedzictwo historyczne,

- dobry stan oczyszczalni ścieków,

- zadowalająca ilość obiektów sportowych,

- dobrze rozwinięta baza gastronomiczna,

- dobrze rozwinięta baza noclegowa,

- działalność Muzeum Regionalnego,

- działalność Miejskiego Ośrodka Kultury,
- monitoring miejski.

\section{SŁABE STRONY}

- znaczny spadek liczby ludności w ostatnich latach,

- brak miejsc pracy,

- migracja osób młodych i wykształconych,

- wysoki poziom bezrobocia,

- niska jakość dróg,

- słabo rozwinięta komunikacja

- uboga oferta rozrywkowo kulturowa,

- niski poziom agroturystyki,

- brak ścieżek rowerowych, szlaków turystycznych,

- brak wypożyczalni rowerów,

- brak turystycznego wizerunku gminy,

- niezadowalająca ilość parkingów (w tym leśnych miejsc postoju i biwakowania),

- brak wykwalifikowanej kadry turystycznej (szczególnie przewodników po regionie),

- słaba promocja regionu,

- niewystarczająca oferta sportowo-rekreacyjna,

- brak dróg rowerowych (asfaltowych, odrębnych od tras samochodowych),

- brak centrum rozrywkowo - rekreacyjnego,

- słabo rozwinięta infrastruktura gazowa, wodociągowa, kanalizacyjna.

\section{SZANSE}

- dworzec kolejowy w ruchu międzynarodowym,

- odnowa parku miejskiego,

- powrót emigrantów z kapitałem,

- możliwość uzyskania środków z Unii Europejskiej,

- bliskość granicy wschodniej,

- budowa autostrady i dróg zjazdowych,

- rozwój szkolnictwa wyższego,

- bardzo dobre warunki do rozwoju agroturystyki,

- modernizacja rolnictwa,

- profesjonalna promocja regionu,

- duża ilość terenów inwestycyjnych,

- rosnące zainteresowanie mieszkańców wielkich miast wypoczynkiem weekendowym w małych miejscowościach w promieniu do $100 \mathrm{~km}$.,

- wzrost zainteresowania nowymi formami wypoczynku (ekoturystyka, agroturystyka, obserwacja przyrody, fotosafari, inne),

- przedsiębiorczość mieszkańców,

- pozytywne nastawienie mieszkańców do rozwoju funkcji turystycznej.

\section{ZAGROŻENIA}

- konkurencja ze strony innych regionów,

- emigracja zarobkowa ludzi młodych i wykształconych,

- niedostateczna ilość miejsc pracy,

- nielegalne zatrudnienie,

- bariery w pozyskiwania środków unijnych,

- brak środków zewnętrznych,

- pogarszający się stan dróg dojazdowych. $\mathrm{Z}$ analizy SWOT wynika, że mocne i słabe strony 
gminy Łuków znajdują się na podobnym poziomie. Mocne strony są efektem zadowalającego zagospodarowania obszaru oraz unikatowych walorów przyrodniczych. Słabe strony są głównie efektem złego zarządzania władz gmin. Brak miejsc pracy, uczelni wyższych oraz centrów rozrywkowych przyczynia się do emigracji osób młodych. Duży wpływ ma również niewystarczająca promocja obszaru gminy, która uniemożliwia turystom poznanie regionu. Szanse na rozwój niewątpliwie tkwią w możliwościach proponowanych przez Unię Europejską. Uzyskane środki należałoby przeznaczyć m.in. na budowę i remonty dróg oraz zagospodarowanie terenów inwestycyjnych, które pomogłoby utworzyć nowe miejsca pracy.

Podsumowując analizę potencjału turystycznego Łukowa i okolic należy wziąć pod uwagę następujące elementy:

- korzystne położenie komunikacyjne terenu. Przez obszar gminy Łuków przebiega węzeł transeuropejskiej magistrali kolejowej który pozwala na pozyskiwanie nowych inwestorów oraz napływ turystów z zagranicy,

- region ma wiele walorów przyrodniczych m.in. unikatowe rezerwaty przyrody, atrakcyjne przyrodniczo tereny wzdłuż rzek Krzna Północna i Krzna Południowa oraz zalew „Zimna Woda”. W przyszłości należałoby te tereny wykorzystać do budowania oferty turystycznej i ciekawych produktów turystycznych. Powstanie nowych ośrodków wypoczynkowych oraz parków rozrywki z pewnością przyczynią się do rozwoju gminy,

- dobre zagospodarowanie turystyczne. Odpowiednia baza gastronomiczna i noclegowa oraz obiekty rekreacyjne stwarzają atrakcyjną pozycję turystyczną dla gminy, Niezbędny jest rozwój gospodarstw agroturystycznych. Region ma wiele walorów przyrodniczych które z pewnością ściągną na tereny turystów chcących z dala od wielkich miast w ciszy i spokoju wypocząć i zrelaksować się.

- gmina ma bogatą historię oraz zabytki, które wpływają pozytywnie na budowanie wizerunku gminy.

- dobrze prosperujące branże: obuwnicze i mięsne, które dają zatrudnienie mieszkańcom, zapewniają wpływy do budżetu z podatków oraz promują region na forum ogólnopolskim,

- $\quad$ w mieście brakuje atrakcyjnych imprez, które mogłyby przyciągnąć turystów. Aktualnie organizacja takich wydarzeń na charakter regionalny,

- brak odpowiednich działań władz gminy związanych z promocja, która mogłaby zwiększyć zainteresowanie wśród turystów jak również inwestorów.

\section{Podsumowanie}

Współczesne trendy w popycie turystycznym wyraźnie wskazują na wzrost popytu na potrzebę kontaktu $\mathrm{z}$ naturą, zamiłowania przyrodnicze, chęć wypoczynku na łonie przyrody, chęć ucieczki od stresu, hałasu, potrzebę przebywania w czystym i nieskażonym środowisku, w którym można w pełni odpocząć fizycznie, psychicznie i duchowo ( Kozak 2012). Warunki te znakomicie spełnia obszar gminy Łuków. Znajomość potencjału turystycznego jest bardzo ważnym elementem pozwalającym na kreowanie ciekawej oferty turystycznej. Planowanie i realizowanie przedsięwzięć inwestycyjnych wydaje się głównym sposobem wcielenia w życie nowych produktów turystycznych. Władze gminy Łuków powinny zaplanować programy operacyjne mające na celu poprawę atrakcyjności gminy. Do zainteresowania obszarem gminy przyczynić się mogą planowane imprezy promocyjne, ciekawa strona internetowa oraz atrakcyjne foldery informacyjne.

Podsumowując, zarówno badania ankietowe jak i analiza SWOT wykazały, że mieszkańcy oraz turyści mino licznych niedociągnięć związanych głównie ze złym zarządzaniem władz, są zadowoleni z zagospodarowania turystycznego oraz walorów przyrodniczych gminy. Oczekują jednak zmian podejścia władz lokalnych do promocji regionu oraz dalszego rozwoju infrastruktury turystycznej.

Odpowiadając na zadane we wstępie pytanie, można stwierdzić, że walory przyrodnicze i antropogeniczne na obszarze gminy Łuków oraz obecne zagospodarowanie turystyczne dają podstawy do zwiększenia ruchu turystycznego. Gmina Łuków to niewątpliwie obszar charakteryzujący się różnorodnością świata przyrody, ciekawym krajobrazem, bogatą historią i występującymi obiektami związanymi z działalnością człowieka. Miejsca o takich cechach są współcześnie podświadomie uzmysławianym gwarantem udanego wypoczynku. Rozwój turystyki na obszarze gminy Łuków powinien mieć zdecydowanie charakter zrównoważonego rozwoju. Powstanie ciekawych, konkurencyjnych produktów turystycznych i rozwój turystyki zrównoważonej (agroturystyki, turystyki edukacyjnej, przyrodniczej) może być w przyszłości ogromną szansą dla obszaru całej gminy i regionu, borykającego się $\mathrm{z}$ trudnościami ekonomicznymi.

\section{Literatura:}

1. Gierszewska G., Romanowska M. (2003), Analiza strategiczna przedsiębiorstwa. PWE, Warszawa.

2. Łukowska Gazeta Jubileuszowa (2003), Łukowskie Towarzystwo Regionalne im. J. S. Majewskiego w Łukowie, Łuków.

3. Kozak A. (2013), Potencjał turystyczny obszarów przyrodniczo-cennych na przykładzie Poleskiego Parku Narodowego, W: Popyt turystyczny, Fundusze Europejskie, Zagadnienie Regionalne. Wydawnictwo Uniwersytetu Szczecińskiego, Szczecin-Kołobrzeg.

4. Program Ochrony Środowiska dla Gminy Łuków na lata 2013-2016, z perspektywa do 2020 roku, Studium uwarunkowań i kierunków zagospodarowania przestrzennego Gminy Łuków (2013). Załącznik Nr 1 do Uchwały Nr X/34/11 Rady Gminy Łuków z dnia 19 kwietnia 2011 r., Łuków.

5. Szczęśniak H. (1983), Łuków i okolice, Informator turystyczny. Lublin- Siedlce. 